A book that devotes a chapter of fourteen pages to intelligence tests, and then gives in an appendix a footrule for intelligence testing, is bound to give the impression that any one with a certain degree of intelligence but without any special knowledge is in a position to apply such tests with fruitful results. Any such impression is erroneous in the extreme, and pays little respect to the psychologists who are experimenting in this field of research and are trying to overcome scientifically some of the difficulties inherent in the subject, which are either not mentioned or passed over so lightly by Dr. Drever.

The fundamental difference between these two books is that the author of one is mainly interested in industrial psychology from the point of view of the lecturer; while the main interest of the author of the other is that of the research worker. Industrial psychology has a long way to go before it can offer much scope for those who wish to lecture profitably about its principles, for most of these have to be discovered by the research worker and tested in various fields before they can claim to rank as truly scientifio. It is because Dr. Vernon has attempted this that his book marks a definite advance in the science and should be read by all who are interested in the human side of industry either from the practical or the scientific point of view.

\section{Glacial Climates.}

Das Klima des Eiszeitalters. By Prof. Dr. R. Spitaler. Pp. iv $+\mathrm{r}_{3} 8$. (Prag: from the author, Smichow, 379. I92r.) $65 \mathrm{~K}$.

R FELIX OSWALD (Nature, vol. lxxv. p. 197) 1 performed a remarkable feat when he printed his "Treatise on the Geology of Armenia" on a handpress at Beeston in 1905. Prof. Rudolf Spitaler has reverted further, and has issued his work on glacial climates in a written script. The reproduction of this by lithography secures a uniformity that was not always possible among the ancients. He thus shows us a way out of the apparent impasse that has threatened scientific publication. The lodging in suitable libraries of, say, a hundred copies of a quarto memoir such as this would go far in the dissemination of ideas, and the process lends itself to tabular matter, freely used by Prof. Spitaler, and also to much delicacy of illustration. Authors in the days of imperial Rome were not dissatisfied with a manuscript mode of publication. The monumental "Naturalis Historia" of the elder Pliny, in thirty-seven books, gained a handsome circulation, and the author was engaged on a supplement-how well we know those supplements !-in the tragic year of 79 . The genial Martial directs a wouldbe borrower to the shop of Attractus opposite Cæsar's forum, in the certainty that a copy of his latest poems could be bought there for five denarii. Allowing for the exchange, Prof. Spitaler asks little more, and we must remember that Roman publishers had the advantage of slave-labour.

In the beautiful script of his amanuensis, Prof. Spitaler supports the astronomical explanation of the climatic changes that produce or abrogate an ice-age. He divides the globe into zones of latitude, and shows how each would be affected by the variation of the perihelion position of the earth, combined with variation in the obliquity of the ecliptic. He lays stress on the distribution of land and water within the zones; climate is greatly affected by "continentality" and "oceanity." This, however (p. 29), does not account for the higher average temperature in January as against July at the equator, which is attributable to the occurrence of perihelion when winter reigns in the northern hemisphere.

A maximum excentricity of the orbit and a high obliquity of the ecliptic provide extreme conditions and promote glaciation; but Prof. Spitaler contends that even in these circumstances there need not be a reversal of the climate of each hemisphere every Io,500 years. He urges (p. III) that a glacial climate, when promoted in the north, may affect the equator and still more the south, so that simultaneous glaciation over the whole earth, as postulated by A. Penck, is possible. Cool summers and mild winters (p. 94) favour snowfall, while hot summers and very cold winters are unfavourable. The maximum of the last warm period for the northern hemisphere (p. 57), when the summer took place in perihelion, is held to have occurred about 8500 years ago, an epoch that coincides presumably with the rapid melting back of the northern ice. The author (p. I3I) looks forward to a continuance of a warm period, controlled by the excentricity, for nearly 500,000 years, when a great ice-age will again begin to affect the earth, unless tectonic changes intervene, such as have no doubt acted in the past. The Permian ice-age (p. r37) may be referred to the greater coolness of the large seaarea lying to the north of Gondwana Land, at an epoch of high excentricity, high obliquity of the ecliptic, with perihelion, as now, in the winter of the northern hemisphere.

In view of recent progress in physics, many geologists will prefer the hypothesis of variations in solar radiation as a possible explanation of great climatic changes; but this will not lessen their interest in Prof. Spitaler's detailed calculations. G. A. J. C. 